\title{
EFEKTIVITAS PEMBELAJARAN NUMBERED HEAD TOGETHER (NHT) DIVARIASIKAN DENGAN MODEL DIRECT INSTRUCTION (DI) TERHADAP HASIL DAN AKTIVITAS BELAJAR SISWA PADA MATERI SISTEM REPRODUKS MANUSIA
}

\author{
Dewi R.W. Simanungkalit ${ }^{1 *}$, Andriana Y.D Lumban Gaol ${ }^{1}$, Berlian Hutabarat ${ }^{2}$ \\ ${ }_{1}^{1}$ Program Studi Pendidikan Biologi, FMIPA, Universitas Negeri Medan, Jl. Willem Iskandar Psr. V, Medan Estate, \\ Medan, Indonesia, 20221 \\ 2SMA Negeri 14 Medan. Jl. Pelajar Timur Ujung Kelurahan Binjai Kecamatan Medan Denai Kota Medan. \\ *Korespondensi Author: dewisimanungkalit001@gmail.com
}

INFOARTIKEL

Histori Artikel

Received 28 Agustus 2018

Revised 14 Januari 2020

Accepted 14 Januari 2020

Published 23 Januari 2020

Keywords:

Efektivitas, Numbered Head Together (NHT), Direct Instruction (DI), Hasil Belajar, Aktivitas Belajar

\begin{abstract}
ABSTRAK
Penelitian ini bertujuan untuk mengetahui efektivitas model pembelajaran kooperatif tipe Numbered Head Together (NHT) divariasikan dengan model pembelajaran Direct Instruction (DI) terhadap hasil daan aktivitas belajar siswa pada materi Sistem Reproduksi di kelas XI IPA SMA Negeri 14 Medan Tahun Pembelajaran 2017/2018. Jenis penelitian ini adalah Eksperimen semu (Quasi Eksperiment), dimana populasi dari penelitian ini adalah seluruh siswa kelas XI IPA SMA Negeri 14 Medan yang 183 orang. Teknik pengambilan sampel yang dilakukan adalah random sampling dimana sampelnya adalah kelas XI IPA 2 yang berjumlah 40 orang. Hasil penelitian menunjukkan bahwa tingkat penguasaan siswa tingkat penguasaan siswa mencapai $80 \%$ termasuk kategori tinggi, Ketuntasan belajar siswa mencapai 92,5\% termasuk kategori tuntas, Ketercapaian indikator mencapai termasuk kategori tercapai 87,25\% termasuk kategori tercapai, dan aktivitas belajar siswa yang mencapai 84,78 termasuk ke dalam kategori aktif. Sehingga dapat disimpulkan bahwa model pembelajaran kooperatif tipe Numbered Head Together (NHT) divariasikan dengan model pembelajaran Direct Instruction (DI) efektif digunakan pada materi sistem reproduksi manusia di kelas XI IPA SMA Negri 14 Medan Tahun Pembelajaran 2017/2018.
\end{abstract}

Copyright (C) 2019 Universitas Negeri Medan. Artikel Open Access dibawah lisensi CCBY-4.0 (https://creativecommons.org/licenses/by/4.0)

\section{How To Cite:}

Simanungkalit, D., Gaol, A.Y.D.L., \& Hutabarat, B. (2019). Efektivitas Pembelajaran Numbered Head Together (NHT) Divariasikan Dengan Model Direct Instruction (DI) Terhadap Hasil dan Aktivitas Belajar Siswa pada Materi Sistem Reproduks Manusia. Jurnal Pelita Pendidikan, 7(4), 161-169. 


\section{PENDAHULUAN}

Mengingat pelajaran biologi adalah pelajaran yang tidak terlepas dari hapalan yang tentunya akan menimbulkan kebosanan dan kejenuhan. Maka sangat diperlukan sekali perhatian dan peran aktif guru dalam memilih penggunaan model pembelajaran yang tepat serta menarik dan menyenangkan bagi siswa sehingga dapat meningkatkan hasil maupun aktifitas belajar siswa.

Materi Sistem Reproduksi Manusia adalah salah satu pokok bahasan pelajaran kelas XI SMA yang membahas mengenai organ-organ reproduksi manusia, proses pembentukan zigot, fertilisasi, pembelahan sel, dan lainnya. Materi ini termasuk salah satu materi pelajaran Biologi yang membutuhkan hafalan serta membutuhkan waktu yang lama jika diajarkan secara konvensional kepada siswa. Maka dari itu, materi sistem reproduksi pada manusia ini sangatlah cocok jika diajarkan dengan model pembelajaran kooperatif, sebab dengan model pembelajaran ini siswa dalam kelompok dapat mendiskusikan secara bersama bagian yang mereka pelajari sehingga hal- hal yang dipelajari dalam materi sistem reproduksi pada manusia dapat terbahas dan dapat berinteraksi terhadap guru maupun sesamanya. Model pembelajaran yang digunakan dalam kegiatan pembelajaran bukan hanya disesuaikan dengan tujuan yang hendak dicapai tetapi disesuaikan pula dengan bahan atau materi pembelajaran serta karakteristik dan kebutuhan siswa.

Berdasarkan hasil observasi yang dilakukan pada hari Sabtu, 27 Januari 2018 di kelas XI SMA Negeri 14 Medan, kurangnya keaktifan siswa selama kegiatan belajar mengajar (KMB) berlangsung, serta pembelajaran biologi yang dilaksanakan masih cenderung menggunakan model pembelajaran yang klasikal karena berdasarkan faktor usia menyebabkan guru tidak mampu menerapkan model kooperatif dikarenakan kondisi fisiknya tidak mendukung, sehingga guru menyampaikan materi dengan metode ceramah atau konvensional ketika mengajar dikelas. Hasil dari wawancara dengan guru biologi yang di SMA Negeri 14 Medan menyatakan bahwa nilai hasil belajar siswa pada materi sistem reproduksi pada manusia masih banyak yang belum mencapai nilai KKM yang telah ditentukan oleh sekolah, dimana nilai KKM mata pelajaran biologi di SMA Negeri 14
Medan yaitu 75 dan dapat disimpulkan banyak siswa yang belum tuntas dalam pembelajaran biologi pada materi Sistem reproduksi pada manusia.

Berdasarkan pernyataan diatas perlu solusi yang dapat dilaksanakan untuk perbaikan dalam proses pembelajaran Biologi sehingga membuat siswa menjadi aktif dalam proses pembelajaran biologi dan hasil belajar biologi siswa meningkat. Salah satu upaya yang dilakukan adalah pembaharuan terhadap model pembelajaran yang dilakukan oleh guru biologi, sehingga proses pembelajaran lebih bervariasi. Dengan adanya pembaruan tersebut, maka kegiatan pembelajaran biologi akan terlihat efektif dan efisien. Untuk itu, peneliti menerapkan model pembelajaran Numbered Head Together (NHT) divariasikan dengan Direct Instruction (DI).

Salah satu model pembelajaran yang dapat diterapkan adalah model pembelajaran kooperatif tipe numbered head together (NHT). Menurut Ibrahim (2010) menyatakan bahwa Pembelajaran Kooperatif Tipe Numbered Head Together (NHT) adalah model pembelajaran yang dirancang untuk mempengaruhi pola interaksi siswa dan memiliki tujuan untuk meningkatkan penguasaan akademik serta mengedepankan kepada aktivitas siswa peserta didik dalam mencari, mengolah dan melaporkan informasi dari beberapa sumber belajar yang akhirnya untuk dipresentasikan di depan kelas.

Model pembelajaran Direct Instruction (DI) langsung adalah Model pembelajaran yang dirancang khusus untuk menunjang proses belajar siswa yang berkaitan dengan pengetahuan prosedural yang terstruktur dengan baik yang dapat diajarkan dengan pola kegiatan yang bertahap, selangkah demi selangkah (Shoimin, 2016). Sehingga dengan model pembelajaran kooperatif tipe numbered head together (NHT) jika divariasikan dengan Model pembelajaran Direct Instruction (DI) dapat mengetahui aktivitas dan hasil belajar siswa kelas XI IPA di SMA Negeri 14 Medan.

Model pembelajaran ini sudah pernah diteliti sebelumnya oleh Riyadi dan Lestari,N., (2015) bahwa Model pembelajaran kooperatif tipe Numbered Head Together (NHT) dapat meningkatkan Hasil belajar siswa dimana Dalam 
siklus 1 nilai pretes ketuntasan klasikal adalah 45\% dan pada siklus II nilai pretes meningkat menjadi $85 \%$. Hasil pretes ini dapat dijadikan sebagai tolak ukur untuk mengukur kemampuan awal siswa sebelum mendapatakan pembelajaran dengan model Numbered Head Together. Kemudian setelah melaksanakan pembelajaran dengan menggunakan model pembelajaran Numbered Heads Together nilai hasil postest siklus I dengan ketuntasan klasikal adalah $70 \%$ dan pada siklus II nilai postes ketuntasan klasikal meningkat menjadi 95\%. Jadi dari data di atas dapat disimpulkan bahwa terjadi peningkatan dari siklus I ke siklus yang ke II.

Penelitian yang dilakukan oleh Hamka L. \& Muhammad Nur Arsyad (2015) menyatakan bahwa Dengan menerapkan model pembelajaraan langsung menunjukkan bahwa nilai rata - rata pretest siswa adalah 33,68 dan nilai rata-rata posttest siswa adalah 71,81. Data ini mengindikasikan bahwa telah terjadi peningkatan hasil belajar siswa setelah diajar menggunakan model pembelajaran langsung, yaitu sebesar 38,13 poin. Data ini mengindikasikan bahwa telah terjadi peningkatan kategori hasil belajar siswa setelah diajar menggunakan model pembelajaran langsung. Berdasarkan hasil dan pembahasan dapat disimpulkan bahwa model pembelajaran langsung efektif diterapkan pada materi sistem gerak di SMA Negeri 1 Donri-donri.

Berdasarkan uraian diatas peneliti ingin menyelesaikan masalah ini, maka peneliti tertarik untuk melakukan penelitian dengan : "Efektivitas Penggunaan Model Pembelajaran Kooperatif Tipe Numbered Head Together (NHT) Divariasikan Dengan Model Direct Instruction (DI) Terhadap Hasil Dan Aktivitas Belajar Siswa Pada Materi Sistem Reproduksi Pada Manusia Di Kelas XI IPA SMA Negeri 14 Medan T.P. 2017/2018".

\section{METODE PENELITIAN}

Pengumpulan data maupun informasi yang dibutuhkan dalam penelitian ini dilaksanakan di SMA Negeri 14 Medan yang beralamat dijalan Pelajar Timur Ujung Kelurahan Binjai Kecamatan Medan Denai Kota Medan. Populasi dalam penelitian ini adalah seluruh siswa - siswi kelas XIIPA SMA N 14 Medan Tahun Pembelajaran 2017/2018 yang terdiri dari 5 kelas XI - IPA yang jumlah keseluruhan siswanya 183 orang. Sampel pada penelitian ini adalah kelas XI IPA2 yang berjumalah 40 siswa. Teknik pengambilan sampel pada penelitian ini adalah random sampling (sampling acak).

Jenis penelitian ini adalah penelitian Eksperimen semu (Quasi Eksperiment). Instrumen penelitian menggunakan tes yang berbentuk pilihan berganda dengan jumlah 25 soal yang sudah divalidkan mengenai materi sistem reproduksi manusia.

Untuk mengetahui keefektifan model pembelajaran kooperatif Numbered Head Together (NHT) divariasikan dengan model Direct Instruction (DI) pada materi Sistem Reproduksi Pada Manusia, maka dilakukan analisis data penelitian dari hasil yang menjadi indikator efektivitas pembelajaran melalui langkah-langkah sebagai berikut.

\section{Tingkat Penguasaan Siswa}

Menurut Harnitayasri, et al (2015) tingkat penguasaan siswa dapat ditentukan dengan memakai hitungan PPS (Persentasi Penguasaan Siswa). Untuk mengetahui sejauh mana tingkat penguasaan siswa terhadap pembelajaran sistem Reproduksi pada manusia digunakan prinsip konversi lima.

$$
P P S=\frac{\text { Skor yang diperoleh }}{\text { Skor maksimum }} \times 100 \%
$$

\section{Ketuntasan Belajar}

Siswa tuntas belajar apabila siswa tersebut telah mencapai skor $75 \%$ atau 75 dan kelas dikatakan tuntas apabila didalam kelas tersebut terdapat $\geq 85 \%$ siswa yang telah tuntas belajarnya. Menurut Trianto (2009) untuk mengetahui ketuntasan belajar secara perorangan (individual) digunakan rumus:

$$
K B=\frac{\text { Jumlah skor yang diperoleh siswa }}{\text { Jumlah skor maksimal }} \times 100 \%
$$

Dengan Kriteria :

$0 \%<\mathrm{K}<75 \% \quad$ : Siswa belum tuntas belajar

$75 \%<\mathrm{K}<100 \%$ : Siswa telah tuntas belajar

\section{Ketercapaian Indikator}

Ketuntasan setiap indikator ditandai dengan menghitung pencapian butir soal berdasarkan criteria ketuntasan yang telah ditetapkan sekolah 
yaitu $\geq 75$. Rumus tingkat ketercapaian indikator menurut Fitra (2016) adalah sebagai berikut:

$$
\mathrm{T}=\frac{S i}{\mathrm{~S} m a k s} \times 100 \%
$$

Keterangan :

$\mathrm{T}=$ = Persentase pencapaian indikator
$\mathrm{Si}=$ = Jumlah skor untuk butir soal ke $-\mathrm{i}$

Smaks = Jumlah skor maksimum untuk butir soal ke $-\mathrm{i}$

Dengan kriteria:

$0 \% \leq \mathrm{T} \leq 75 \%$ : Indikator belum tercapai

$75 \% \leq \mathrm{T} \leq 100 \%$ : Indikator telah tercapai

\section{HASIL DAN PEMBAHASAN}

\section{Hasil Belajar Siswa}

Nilai hasil belajar siswa diperoleh dari tes yang dilakukan di awal dan akhir proses pembelajaran yaitu nilai rata - rata siswa saat diberi

- rata siswa saat diberi tes akhir (Post - Test) yaitu 80. Dibawah ini adalah perbandingan nilai pre-test dan post-test siswa kelas XI IPA 2 SMA Negeri 14 Medan.

Tabel 1. Persentase Hasil Belajar Siswa Saat Tes Awal (Pre -Test)

\begin{tabular}{ccccc}
\hline No & Nilai Tes & Kriteria Hasil Belajar & Banyak Siswa & Persentase Siswa \\
\hline 1 & $0-59$ & Sangat Rendah & 15 & $37,5 \%$ \\
2 & $60-69$ & Rendah & 17 & $42,5 \%$ \\
3 & $70-79$ & Sedang & 6 & $15 \%$ \\
4 & $80-89$ & Tinggi & 2 & $5 \%$ \\
5 & $90-100$ & Sangat Tinggi & 0 & $0 \%$ \\
\hline
\end{tabular}

Tabel 2. Persentase Hasil Belajar Siswa Saat Tes Akhir (Post Test)

\begin{tabular}{ccccc}
\hline No & Nilai Tes & Kriteria Hasil Belajar & Banyak Siswa & Persentase Siswa \\
\hline 1 & $0-59$ & Sangat Rendah & 4 & $10 \%$ \\
2 & $60-69$ & Rendah & 6 & $15 \%$ \\
3 & $70-79$ & Sedang & 7 & $17,5 \%$ \\
4 & $80-89$ & Tinggi & 19 & $48 \%$ \\
5 & $90-100$ & Sangat Tinggi & 3 & $7,5 \%$ \\
\hline
\end{tabular}

Dari kedua tabel diatas jika dibandingkan jelas terlihat adanya peningkatan hasil belajar siswa pada pembelajaran yang menggunakan model pembelajaran NHT (Numbered Head Together) divariasikan dengan DI (Direct Instruction) pada materi sistem reproduksi. Hal ini hasil pre - test siswa menunjukkan bahwa nilai tertinggi adalah 76 dan nilai terendah adalah 12 . Rendahnya hasil belajar siswa pada saat pretes tersebut karena belum mendapatkan pengajaran mengenai materi sistem reproduksi manusia sehingga siswa sama sekali belum mengetahuan dan memahaminya. Sedangkan untuk hasil postes menunjukkan bahwa nilai tertinggi adalah 92 dan nilai terendah adalah 57. Untuk jelaskan dapat dilihat diagram batang berikut. 




Gambar 1. Diagram batang Pre-Test dan Post-Test

\section{Aktivitas Belajar Biologi Siswa}

Observasi aktivitas belajar siswa dilakukan selama kegiatan belajar mengajar berlangsung oleh tiga orang pengamat (observer) yang telah dilengkapi dengan lembar observasi. Adapun jenis aktivitas belajar siswa yang telah diamati adalah : 1) Aktivitas melihat atau memperhatikan penjelasan guru,2) Aktivitas mendengarkan, 3) Aktivitas lisan atau memberikan saran dan tanggapan, 4) Aktivitas menulis, 5) Aktivitas emosional, 6) Aktivitas mental. Aspek - aspek tersebut diberi skor 1 - 4 dengan berpedoman observasi aktivitas siswa.

Berdasarkan hasil aktivitas belajar siswa yang diperoleh dengan menggunakan model pembelajaran NHT (Numbered Head Together) divariasikan dengan DI (Direct Instruction) menunjukkan skor rata - rata aktivitas siswa mencapai nilai 84,78 yang termasuk ke dalam kategori aktif. Skor rata - rata aktivitas siswa di kelas XI - IPA 2 SMA Negeri 14 Medan dengan menggunakan model pembelajaran NHT (Numbered Head Together) divariasikan dengan DI (Direct Instruction) pada materi sistem reproduksi manusia adalah 16 siswa termasuk ke dalam kategori sangat aktif (85-100), 19 siswa termasuk ke dalam kategori aktif $(75-84), 5$ siswa termasuk ke dalam kategori cukup aktif (60 - 74), dan tidak ada siswa yang termasuk ke dalam kategori kurang aktif (50 - 59). Dan hasil observasi aktivitas belajar siswa dapat dilihat pada Tabel 3 .

Tabel 3. Distribusi Frekuensi Skor Rata - Rata Aktivitas Belajar Siswa

\begin{tabular}{cccc}
\hline No & Skor & Kategori & Frekuensi \\
\hline 1 & $85-100$ & Sangat aktif & 21 \\
2 & $75-84$ & Aktif & 14 \\
3 & $60-74$ & Cukup aktif & 5 \\
4 & $50-59$ & Kurang aktif & 0 \\
\hline
\end{tabular}

\section{Tingkat Penguasaan Siswa}

Dari hasil pengolahan data skor rata - rata tingkat penguasaan siswa, terlihat jelas tingkat penguasaan siswa sebelum diberikan pengajaran dengan model pembelajaran NHT (Numbered Head Together) divariasikan dengan DI (Direct Instruction) tingkat penguasaan siswa pada materi sistem reproduksi manusia di kelas XI IPA 2 SMA N.14 Medan termasuk dalam ketegori rendah. Jika dibandingkan tingkat penguasaan siswa pada pre test sangat jauh berbeda dengan tingkat penguasaan siswa pada post - test hasilnya berbanding terbalik. Dimana dari hasil pretest diketahui bahwa terdapat 4 siswa yang memperoleh tingkat penguasaan dengan kategori sangat rendah, 6 siswa yang memperoleh tingkat penguasaan dengan kategori rendah, 7 siswa yang memperoleh tingkat penguasaan dengan kategori 
sedang, 19 siswa yang memperoleh penguasaan dengan kategori tinggi dan 3 siswa yang memperoleh tingkat penguasaan dengan kategori sangat tinggi. Sedangkan dari skor rata - rata tingkat penguasaan siswa pada saat post-test adalah sebesar 80 sehingga dapat disimpulkan bahwa secara umum tingkat penguasaan siswa pada materi sistem reproduksi manusia di kelas XI IPA 2 SMA Negeri 14 Medan Tahun Pembelajaran 2017/2018 setelah diberikan pengajaran dengan model pembelajaran NHT (Numbered Head Together) divariasikan dengan DI (Direct Instruction) tergolong kategori tinggi.

\section{Ketuntasan Belajar Siswa}

Dalam menganalisis ketuntasan belajar, ada dua hal yang harus diperhatikan yaitu, ketuntasan belajar secara individual dan ketuntasan belajar secara klasikal. Siswa dikatakan tuntas apabila nilainya $\geq 75$ dan kelas dinyatakan tuntas bila $85 \%$ atau lebih dari keseluruhan siswa berhasil tuntas.Tingkat penguasaan belajar siswa diketahui dari hasil post - test atau setelah diberikan pengajaran dengan menggunakan model pembelajaran NHT (Numbered Head Together) divariasikan dengan model pembelajaran DI (Direct Instruction). Adapun persentase tingkat ketuntasan belajar siswa pada materi Sistem Reproduksi Manusia pada tabel 4 berikut.

Tabel 4. Ketuntasan Belajar Siswa

\begin{tabular}{ccccc}
\hline \multicolumn{5}{c}{ Persentase Tingkat Ketuntasan Siswa } \\
\hline No & Nilai Tes & Tingkat Ketuntasan & Banyak siswa & Persentase siswa \\
\hline 1 & $\leq 75$ & Tidak Tuntas & 3 & $7.5 \%$ \\
2 & $\geq 75$ & Tuntas & 37 & $92.5 \%$ \\
\hline
\end{tabular}

Dari hasil pengolahan data berdasarkan tabel persentase diatas, data serap siswa diperoleh hasil bahwa secara individu, terdapat 37 siswa atau $92,5 \%$ dari keseluruhan siswa dinyatakan tuntas dalam belajar karena telah memperoleh persentase tingkat penguasaan antara $75 \%-100 \%$. Sedangkan secara klasikal (kelompok), kelas XI IPA 2 SMA Negeri 14 Medan Tahun Pembelajaran 2017/ 2018 dinyatakan tuntas dalam belajar karena hanya 3 siswa yang tidak tuntas dalam belajar, yang berarti lebih dari $85 \%$ keseluruhan siswa yang sudah tuntas secara individual dan kelas tersebut dinyatakan tuntas secara klasikal (kelompok).

\section{Ketuntasan Pencapaian Indikator}

Suatu indikator dikatakan tercapai apabila hasil yang dicapai siswa dalam tes adalah $75 \%$ dari seluruh indikator yang telah ditetapkan. Perhitungan tingkat pencapaian indikator selanjutnya dapat dilihat pada. Ketuntasan pencapaian indikator secara keseluruhan dilihat dari jumlah pencapaian 6 indikator telah tercapai sehingga dapat disimpulkan bahwa ketercapaian indikator yang diajukan dalam melaksanakan pembelajaran biologi pada materi sistem reproduksi pada manusia di kelas XI IPA 2 SMA Negeri 14 Medan Tahun Pembelajaran 2017/2018 secara keseluruhan tercapai karena masing masing indikator memiliki nilai rata - rata $>75 \%$.

Berdasarkan hasil analisis data yang dilakukan dapat disimpulkan bahwa hasil belajar siswa meningkat, dimana sebelum diadakan pengajaran menggunakan model pembelajaran Numbered Head Together (NHT) Divariasikan dengan model pembelajaran Direct Instruction (DI), peneliti terlebih dulu memberikan pretest kepada siswa berupa soal. Dari hasil pretest tersebut diketahui masih banyak tergolong kedalam kategori sangat rendah dan rendah.

Sementara setelah diberikan pengajaran dengan model pembelajaran Numbered Head Together (NHT) Divariasikan dengan model pembelajaran Direct Instruction (DI), terdapat peningkatan di hasil post - test. Dimana rata - rata nilai pretest adalah 41,1 sedangkan rata - rata nilai post - test adalah 80. Dari hasil penelitian ini model pembelajaran Numbered Head Together (NHT) Divariasikan dengan model pembelajaran Direct Instruction (DI) efektif dalam peningkatan hasil belajar siswa. Sehubungan dengan hal tersebut menurut Eka Lestari, Uswatun Hasanah dan Dahliana Siregar (2017) berpendapat bahwa dengan menggunakan model pembelajaran kooperatif tipe Numbered Head Together (NHT) mengajarkan siswa bekerjasama dengan 
kelompoknya dan bertanggungjawab untuk menguasai materi pembelajaran yang ditugaskan kepadanya, karena setiap siswa diwajibkan untuk menjawab pertanyaan yang diberikan guru, sehingga siswa mengalami suatu pembelajaran yang efektif.

Hal ini diperkuat oleh peneliti sebelumnya yang dilakukan oleh Wahyuningsih dan Murwani (2015) yang menyimpulkan bahwa penerapan model kooperatif Learning tipe NHT dapat meningkatkan hasil belajar siswa dilihat dari pemahaman konsep. Hal ini terbukti dari hasil peningkatan pada siklus I rata - rata hasil pretes siswa sebesar 64,23 dan hasil postest rata - rata siswa mencapai 74,17. Pada siklus II rata - rata hasil pretes siswa sebesar 61,37 dan hasil postest ratarata siswa mencapai 78,06. Pemahaman konsep siswa mengalami peningkatan, hal ini terlihat dari besarnya hasil perhitungan skor hasil pretest dan postest (gain) yang dilakukan dalam setiap siklus.

Disamping itu penelitian yang dilakukan oleh Kholilah Amriani Harahap dan Surya Dharma Barus (2017), menyatakan bahwa model pembelajaran Kooperatif Tipe Numbered Head Together dapat meningkatkan hasil belajar siswa, dimana pada saat diberikan pretest siswa yang tuntas hanya 9 orang atau $32,14 \%$ dan tidak tuntas 19 orang atau $67,86 \%$. Setelah diberikan perlakuan pada Siklus I yang tuntas sebayak 15 orang atau $53,57 \%$ dan tidak tuntas 13 orang atau $46,43 \%$. Pada Siklus II siswa yang tuntas 24 orang atau $85,71 \%$ dan tidak tuntas 4 orang atau 14,29\%. Dari data ini terdapat peningkatan hasil belajar siswa setelah diajarkan dengan menggunakan model Kooperatif Tipe Numbered Head Together.

Hal ini sejalan juga dengan penelitian Hamka L. dan Muhammad Nur Arsyad (2015), penerapan model pembelajaran langsung (DI) efektif dalam meningkatkan hasil belajar siswa, dimana hasil rata - rata pretest siswa adalah 33,68 dan nilai rata-rata posttest siswa adalah 71,81 terdapat peningkatan hasil belajar siswa setelah diajar menggunakan model pembelajaran langsung.

Peneltian Hasruddin dan Riana (2016), hasil analisis data menunjukkan rata - rata hasil belajar siswa menggunakan model NHT adalah 80 lebih baik dari rata - rata hasil belajar siswa menggunakan model STAD yaitu 71,94 dan terdapat perbedaan serta peningkatan hasil belajar dari perbandingan antara model NHT dan STAD pada materi sistem pencernaan manusi di kelas VIII SMP Negeri 1 Tanah Jawa Kabupaten Simalungun Tahun Pembelajaran 2015/ 2016.

Penguasaan model pembelajaran

Numbered Head Together (NHT) Divariasikan dengan model pembelajaran Direct Instruction (DI) dalam melaksanakan kegiatan belajar mengajar, penelitian juga memberikan pengaruh yang besar dalam membantu siswa untuk memahami materi sistem reproduksi manusia tersebut. Dimana melalui pembelajaran dengan model pembelajaran Numbered Head Together (NHT) Divariasikan dengan model pembelajaran Direct Instruction (DI) ini memberikan kesempatan untuk saling bertukar pikiran atau berdiskusi dan dituntut untuk bertanggung jawab menjawab pertanyaan dengan tepat melalui diskusi belajar.

Untuk ketuntasan belajar, berdasarkan hasil belajar siswa yang diperoleh baik secara individu maupun secara klasikal dinyatakan tuntas dalam belajar. Berdasarkan hasil belajar siswa terdapat 37 siswa yang telah memperoleh nilai $\geq 75$ dan terdapat 3 siswa yang belum tuntas secara individual. Persentase ketuntasan belajar secara klasikal telah mencapai $92,5 \%$ yang berarti telah memenuhi standar minimal tercapainya ketuntasan belajar secara klasikal. Menurut peraturan dalam Trianto (2010) dinyatakan bahwa suatu kelas dikatakan telah lulus belajar jika 85\% siswa dikelas tersebut telah mencapai skor sebesar $75 \%$ atau minimum nilai 75 dari skor maksimal.

Berdasarkan data yang diperoleh dari tingkat ketercapaian indikator terlihat bahwa dari 6 indikator yang ada, semua indikator telah tercapai. Berdasarkan kriteria pencapaian indikator yang dikutip dalam Avriadiana, et al (2013), bahwa " apabila 65\% atau lebih dari seluruh indikator yang ditetapkan tercapai, maka ketuntasan indikator telah tercapai. Dengan kriteria ketuntasan indikator adalah apabila paling sedikit $75 \%$ dari seluruh indikator yang sudah tercapai", maka dengan demikian secara keseluruhan indikator dalam Materi Sistem Reproduksi Manusia telah tercapai, terlihat bahwa ketercapaian indikator secara keseluruhan telah terpenuhi dari batas minimum $75 \%$. 
Dalam kegiatan pembelajaran ini diketahui menggunakan model pembelajaran NHT (Numbered Head Together) divariasikan dengan model pembelajaran Direct Instruction (DI) bahwa kemampuan siswa meningkat, baik itu kemampuan bertanya, kemampuan menyatakan pendapat dan kemampuan menjawab pertanyaan di depan kelas. Disaat berdiskusi dalam kelompok, setiap anggota yang lebih paham terhadap materi pelajaran atau tugas yang diberikan membantu siswa yang kurang paham sehingga setiap anggota kelompok memiliki peran dan tanggung jawab masing - masing dalam kegiatan diskusi.

Selain melihat hasil belajar siswa, peneliti juga ingin melihat aktivitas belajar siswa.Dengan adanya kerja kelompok, selain memudahkan siswa untuk memahami materi, siswa juga akan dilatih bagaimana cara berinteraksi dan berkomunikasi yang baik, serta menghargai pendapat orang lain. Namun tidak menutup kemungkinan juga, masih adanya beberapa siswa yang kurang percaya diri dalam menyampaikan pendapatnya. Karna setiap siswa itu memiliki karakter yang berbeda - beda, dimana ada siswa aktivitas melihatnya, aktivitas mendengarnya, aktivitas menulisnya meningkat tapi bisa saja pada aktivitas lisan, emosional, dan mentalnya siswa tersebut kurang. Dan begitu sebaliknya aktivitas melihat, mendengar dan menulisnya kurang tetapi bisa jadi aktivitas lisan. Emosional dan mental siswa meningkat. Maka dari itu diperlukan lebih dari satu orang observer utnuk mengamatinya.

Meningkatnya keaktifan siswa dalam belajar dapat meningkatkan prestasi belajar siswa. Hal ini diperkuat oleh Hamid (2011) yang menyatakan jika siswa aktif dalam pembelajaran maka siswa lebih mengingat lama (retention rate of knowledge) mata pelajaran yang diberikan. Peningkatan prestasi belajar ini menunjukkan terjadinya proses belajar pada siswa. Dengan demikian, dapat disimpulkan bahwa penerapan model pembelajaran NHT (Numbered Head Together) divariasikan dengan model pembelajaran Direct Instruction (DI) efektif digunakan pada materi sistem reproduksi manusia di kelas XI IPA 2 SMA Negeri 14 Medan Tahun Pembelajaran 2017/2018.

\section{KESIMPULAN}

Berdasarkan hasil penelitian yang telah dilakukan dapat diambil kesimpulan bahwa pembelajaran biologi dengan menggunakan model pembelajaran kooperatif tipe Numbered Head Together (NHT) divariasikan dengan model pembelajaran Direct Instruction (DI) pada Materi Sistem Reproduksi Manusia kelas XI IPA 2 SMA Negeri 14 Medan Tahun Pembelajaran 2017/2018 dilihat dari tingkat penguasaan siswa mencapai $80 \%$ termasuk kategori tinggi, ketuntasan belajar siswa mencapai 92,5\% termasuk kategori tuntas dan ketercapaian indikator mencapai 87,25\% termasuk kategori tercapai. Serta aktivitas siswa mencapai 84,78 termasuk dalam kategori aktif. Model pembelajaran kooperatif tipe Numbered Head Together (NHT) divariasikan dengan model pembelajaran Direct Instruction (DI) efektif digunakan dalam materi Sistem Reproduksi Manusia.

\section{DAFTAR PUSTAKA}

Avriadiana, Nurita, Endah, Harumi, Dian dan Septi, (2013), Penyelesaian Soal Secara Sistematis Pada Materi Sistem Persamaan Linear Dua Variabel Dengan Menggunakan Metode Ekspositori, Jurnal Pendidikan Matematika STKIP PGRI Sidoarjo, Vol 1 No.2, September 2013, ISSN 2337 - 8166, STKIP PGRI Sidoarjo.

Fitra, A., (2016), Pembelajaran Menggunakan Metode Think-Pain Share Pada Pokok Bahasan Perpangkatan Bilangan Bulat Untuk Meningkatkan Kemampuan Pemecahan Masalah Siswa Di Kelas VII SMP Kemala Bhayangkari 1 Medan, Jurnal Matik Penusa, 19 (1): $102-110$.

Hamid, M.S. 2011. Metode Edutainment. Diva Press. Jakarta.

Harnitayasri, Nurhayati, dan Irma S., (2015), Efektivitas Model Pembelajaran Problem Based Learning (PBL) Terhadap Hasil Belajar Biologi Siswa Pada Materi Pencemaran Lingkungan Di Kelas X SMA Negeri 2 Polewali. Jurnal Bionature, 16(2):101 - 109.

Hasruddin dan Riana. (2016). Perbandingan Model Pembelajaran Kooperatif Tipe NHT Dengan STAD Terhadap Hasil Belajar Siswa Pada Materi Sistem Pencernaan Manusia, Jurnal Pelita Pendidikan, 2(4): 1 - 9.

Hamka L dan Arsyad, M.N. (2015). Keefektifan Penerapan Model Pembelajaran Langsung 
Pada Materi Sistem Gerak Di SMA Negeri 1 Donri-Donri. Jurnal Bionature, 16 (1) : 5-64.

Kholilah, A., H., dan Surya, D.B. (2017). Penerapan Model Pembelajaran Kooperatif Tipe Numbered Head Together (NHT) Untuk Meningkatkan Hasil Belajar Matematika Siswa. Jurnal Semnastika UNIMED. ISBN: 978 $-602-17980-9-6$.

Lestari, E., Hasanah, Uswatun, dan Siregar, D. (2017). Efektivitas Model Pembelajaran Kooperatif Tipe Numbered Head Together (NHT) Terhadap Hasil Belajar Siswa Pada Materi Sistem Reproduksi Manusia di kelas XI SMA Negeri 1 Air Joman T.P 2016/2017. Jurnal Pendidikan Matematika dan Sains, 12 (1): $1-6$.

Lestari, N., C, dan Riyadi, A. (2015). Peningkatan Hasil Belajar Kognitif Siswa Kelas X - 2 SMAN 1 Muara Pada Materi IPA Konsep Ekosistem Menggunakan Model Pembelajaran Kooperatif Tipe NHT. Cendikia, 9 (1) : 171 166.

Shoimin, A. (2016). 68 Model Pembelajaran Inovatif Dalam Kurikulum 2013, AR - RUZZ Media, Yogyakarta.

Suryosubroto. (2009). Proses Belajar Mengajar Di Sekolah. Penerbit Rineka Cipta, Jakarta.

Trianto, (2009). Mendesain Model Pembelajaran Inovatif -Progresif. Kencana Prenada Media Group, Jakarta.

Wahyuningsih, D., dan Murwani, S. (2015). Peningkatan Aktivitas dan Hasil Belajar Siswa pada Pembelajaran Bilogi Melalui Implementasi Model Numbered Head Together Pada Siswa Kelas XI SMA Negeri 2 Yogyakarta. Jurnal Pendidikan Matematika dan Sains Tahun III. 1:65 - 71. 